\author{
Agnieszka Lipska-Sondecka \\ Pomeranian University (Poland) \\ ORCID: https://orcid.org/0000-0001-8911-4087 \\ e-mail: agalipska@wp.pl
}

\title{
Model Changes of Polish Public Administration and Processes of Political and Structural Transformation
}

\begin{abstract}
The model transformations of Polish public administration after 1989 were the result of the necessary and inevitable consequence of events related to erosion and the collapse of the „real socialism” system. Its internal decomposition, as a result of social reality inadequacy, created a situation in which it was possible to undertake deep systemic reforms in Poland. Democratization of the government system in Poland was an extremely complex process generating numerous problems and showing the scale of adversity in all spheres of social life. All political and structural changes in Poland after 1989 were also possible due to propitious external, international conditions. Especially the collapse of the USSR brought certain possibilities for Poland and other countries in Central and Eastern Europe to regain full sovereignty, which was later expressed in membership in NATO, the Council of Europe, and then European Union accession. As a result of the systemic and political transformation process, the administration has become an extremely important cell in the democratic legal order and the entity responsible for the implementation of a significant part of public tasks at the local, supra-local and regional levels.
\end{abstract}

Keywords: political system, the reforms of political system, administrative apparatus, public administration, transformation

Political and structural transformation meant the modification of all elements of the governmental system as well as its organs and institutions (Antoszewski, 2014). The phenomena that appeared much earlier were not only indicating the collapse of the (socialist) system order but also, they were the announcement of changes concerning the systemic essence of socio-political order. Reforms of the 1970s were an attempt to strengthen the system which foundations proved to be structures not adapted to the requirements of the then social and economic reality. It should be noted that even solutions which were successfully tried in democratic systems did not bring the expected results. The main issue here is the separation 
of the executive apparatus (administration) from the national councils (1972-1973). Yet, the separation mentioned above could not be consequent (Żukowski,2011). The doctrine of governmental uniformity and indivisibility of the socialist state was still in force. However, the creation of a separate executive apparatus had nothing to do with the Montesquieu doctrine of the division of governmental powers. The reform of the 1970s was an attempt to find a solution for the system which revealed other symptoms of erosion. In spite of propaganda concerning political declarations the new territorial division of the state (1975), the abolition of counties and the creation of 49 voivodships, did not contribute, in any way, to deconcentration, let alone decentralization of governmental power (Rybicki, 1988). In fact, these solutions favoured centralization as they weakened the position of party and state authorities in new, territorially small voivodships.

The second half of the seventies is the time of consecutive increase of crisis symptoms, concerning economy, in social relations and political life. The idea of the superior role of the party to the state and its apparatus, which was played very consequently by the management of Polish United Workers' Party, became a system element which hampered the modernization of the country (Mażewski, 2011). This process could not be stopped by the reforms of the central administration, the economic apparatus (which was a part of the state apparatus) or the adaptation of organizational solutions of the territorial government body to the concept that was already being implemented at the level of municipalities. The expected economic results were not brought by investments which were based mainly on loans taken from western countries.

These two "traps" (loans and investments) became crucial aspects bringing economic crisis. The principles and mechanisms of national economy governing system became inefficient as well. These phenomena occurred unstoppable even in the face of political and organizational actions undertaken by the "management of the party and state". Subsequent political programs of the PUWP accompanied by the support of the allied parties: The United People's Party and the Democratic Party, which proclaimed the moral and political unity of the nation or the socialist renaissance, practically turned out to be a complete fiasco.

Their principles were far away from the real status of social relations, level of community integration and a degree of particular milieus' political activities. Any attempts to reform the central state system were also based on the departmental Poland model. The same approach was implemented in relation to territorial authorities - national councils. Moreover, against actual competences, national councils were forcefully tried as social self-government body and, from 1983, even local self-government (Leoński, 1989). Although legal act defined national councils as authorities of the state government bodies and basic economic and territorial self-government organs, in practice, they remained an important element of state apparatus. The unsuccessful attempt to create a semblance of social relations' standardization was carried out by calling national councils by the name of local government organs (Marszałek-Kawa, Lutrzykowski, 2008; Lipska-Sondecka, 2015). However, the most emphatic signal indicating the direction of the pompously announced,,socialist renaissance” 
in political sphere was the amendment to the Polish People's Republic Constitution of the of February 10,1976, which established the role of the party in society and the leadership role of PUWP towards the state and its apparatus as the systemic guideline principle (Mażewski, 2011). The Polish United Workers' Party based its leadership role on three mechanisms: the first, which established the programming and planning mode of the state apparatus action, the second - consisting in entrusting the implementation of the party's political program to the management of individual organs and institutions which were subordinate to particular party instances. The third mechanism was political control and evaluation of activity of particular institutions and their managements (Lutrzykowski, 2018; MarszałekKawa, 2019). Authorities and administrative institutions in the state of real socialism at the level of executive power (using political concepts different from those used in Poland at the time) were the most important factors responsible for the practical implementation of program guidelines formulated at successive PUWP congresses and other party bodies.

Thus, human resources policy was a key element of the government's activities within the process of subordinating particular areas of social life.

The study of the then state administration functioning brings an undisputable conclusion that the relationship between the party leadership and the state administrative apparatus was based on simple connection. Paraphrasing this statement in relation to theoretical and systemic categories the state administration was deprived of any independence which concerned even the matters of its internal functioning (interdiction). This state was also visible in relation to the administration's personnel, their recruitment process and especially the casting of managerial positions. Here, with full consequence, the principle of the party's nomenclature of positions was obeyed, which, in the official language, was referred to as the party's personnel policy (Jarosz, Zawadzki, 1980, p. 126).

The reforms of the central and local administration undertaken in the following years, up to the end of the eighties of the twentieth century, were series of unsuccessful, not adequate to real requirements and challenges, attempts to partially modify the structure of the state, rules of human resources' action and recruitment. Meanwhile, real processes which occurred in Polish society, during the period, required systemic - holistic changes.

Workers strikes taking place on the Coast and other parts of the country in the summer of 1980 were an expression of the growing strength of people who were united by the lack of hope to improve their fate. A new consciousness was born not only among the striking workers but also in the wider spheres of society. A sense of community and a strong bond between the participants of these events became the basis for initiating deep social and political changes (Lutrzykowski, 2014, pp. 174-186). Over time, it became clear that the current system of power, particularly the way it was exercised, did not ensure the implementation of the party's slogan: To make Poland grow in strength and make people prosper. Cases concerning mass social protests against party and state policies, in the form of stormy speeches, mainly in the bastions of so-called large industrial class, were finally controlled and pacified. Political management ignored the conclusions that came from the 
experiences of Polish August, 1980 and subsequent events, i.e. 1956 and 1970. The dual state had complete exclusivity to solve the problems of the collective national life and to decide on the direction of the country's development. Remaining in the circle of Soviet domination and the resulting limited sovereignty was ultimately the factor which limited the possibility of any democratic modernization of the state. Such changes would undermine the systemic principles of real socialism.

Reforms of the governmental system in the spirit of free Western world would require the then authorities to respect even the most important achievements of Polish August, 1980. It was the time of the first systemic breakthrough which expressed the consent of the authorities to create independent, self-governing trade unions. This substitute for political pluralism was quickly annihilated. Martial law broke all the hopes connected with it.

The phenomenon of democratic forces consolidation in the country, initiated after the August, 1980 events, was definitely stopped by the then authorities (detention). Maintaining the order of real socialism at the time could not be helped by changes in the government apparatus. Despite significant personnel changes in the central and administrative party apparatus as well as propaganda and managerial positions in the field, number of people who respected and followed the instructions of the party's Political Bureau without any objections was decreasing in the PUWP's leadership group (Sowa, 2011, pp. 450-451). The militarization of many factories and public institutions did not help either. The „socialist community discipline" did not rise and the authority of the governmental apparatus, including administration, was definitely lowered. In the social consciousness there was a growing conviction that the system of power was being expended. Attempts to maintain the current order of the political system were doomed to failure, which was caused, mainly, by increasingly obvious resistance of the society. Against all intentions of the Military Council for National Salvation opposition activities were not abolished. The conspiratorial structures of Solidarity and other democratic opposition groups were strengthened by taking up opposition activities on a large scale. In the consciousness and attitudes of Polish society martial law caused significant re-evaluations, deepening the dichotomy: we - society and them - the authority (Lutrzykowski, 2014, pp. 186-186).

The deepening multidimensional crisis also caused a number of changes in the central leadership of the PUWP. The advocates of the reform trend began to be heard (Sowa, 2011, p. 610). Support from allied parties such as the United People's Party and the Democratic Party was reduced as well. The situation led to the polarization of positions at the very top of authority power and decisions of the party's management concerning a dialogue with the opposition. After tough PUWP leaders' disputes that regarded a huge discrepancy in the assessment of the situation in the country and its causes, further discussions with the opposition, called the round of the Round Table, were finally made. One of the basic elements of these talks was the democratic modernization of the entire power system, including, in particular, the reconstruction of the administration apparatus. In the first phase of the negotiations there was a strong emphasis on the necessity of restoring territorial self- 
government. The action required changes in the Constitution. Members of the teams which were discussing the issues of the political and social system managed to create foundations for a significant reconstruction, which reinforced the possibility for civil rights implementation. Very important findings concerned the structure of the government apparatus in the state. Establishment of local self-government on March 8, 1990 opened a new stage in the development of Polish administration and the emergence of a dual public authority structure. Establishment of territorial self-government (only at the level of community) meant exclusion of the commune self-government part from the whole area of competence which belonged to state authority (Domarańczyk, 1990). Henceforth, it was possible to talk about the renaissance of public administration in Poland as some of the major social tasks were transferred to the competence of local self-government. Its executive bodies, along with the auxiliary apparatus, became, as well as the government administration, an integral link of public administration and, in a wider perspective, the system of public authority.

Reforms of the eighties and nineties of the last century which were implemented as part of major system reforms introduced a new political order at the level of the commune, and also, from January 1, 1999, at the level of restored (after nearly 25 years) counties and voivodships in their new shape. Reconstruction of territorial self-government as an integral part of the public authorities system was not easy and revealed differences of opinions and views among supporters of self-government but also within the group of the political elite that rooted in the era of real socialism (Regulski, 2000; Pokładecki, 1996). Two different visions of the state systemic order collided. The collision included mainly the methods of exercising power. Advocates of deep systemic political changes strove to democratize by decentralizing the system of power. Their opponents strongly defended the idea of homogeneous and indivisible state power (Lutrzykowski, 2006, pp. 306-307).

Despite the various inhibitions, which sources were also in the central government apparatus and the resistance of various social environments, the new "face" of Polish public administration was slowly evolving. It became an important element of the executive power in the Montesquian approach, whereas the establishment of self-government at the level of the commune (1990) was a breakthrough in the process.

The turn towards the West, visible from the beginning of the Polish transformation, resulted in the acquisition of the democratic achievements of Western European countries. Poland actively participated in the activities of international and supranational European structures, implementing the standards of organization and operation of the public authorities system for internal use. The ratification of the European Charter of Local SelfGovernment (1993) definitely brought Polish local self-governing solutions as well as those in the sphere of public administration closer to these positively verified not only in Western countries.

The European Charter of Local Self-Government and the European Charter of Regional Self-Government (despite the character that is non-existing until today) have become important reference points and sources of the so-called soft law in the process of harmonizing 
organizational solutions and regulations of local government structures' actions in Poland. The harmonization process was also supposed to facilitate partner-like cooperation between local governments on the European scale (Szewc, 2006). The efforts which were undertaken to make Poland join the European Union were another important factors accelerating the reforms of administration structures as well as their democratization and consolidation.

Public administration, in accordance with the program of democratic modernization of the state, became the subject responsible for the implementation of a significant part of public tasks at the local, supra-local and regional levels. This involved the necessity to adopt the legal achievements of the European Union - acquis communautaire. In the process of European integration, a special role was given to the administration as it became responsible for the implementation of union law (Nowak-Far A., 2008). New entities responsible for carrying out tasks in the field of the EU policies implementation were created as well as "tools" that made their implementation possible. An important role was also played by the clerical staff. Their knowledge, skills and competences turned out to be extremely important when considering the quality of Poland's membership in the European Union.

Poland's accession to the EU structures has contributed to changing the position and function of public administration on all its levels (municipalities, counties and provinces). Public administration has become an extremely important entity responsible for carrying out public tasks. The efficiently working administration is a causative factor that shapes a positive image of the state in the eyes of its citizens, affects the better quality of performed tasks and may become a factor that accelerates civilizational and cultural progress. The role of administration in articulating the needs and social expectations cannot be then overestimated. This means the transformation processes in the area of administration are still valid and not entirely closed. The problems of model transformations of Polish public administration in the context of transformational changes should remain the field of important reflections and proposals concerning organizational, normative and functional solutions that should serve civilizational and cultural progress.

\section{References}

Antoszewski, A. (2014). “Od tranzycji do autorytaryzmu i jego konsolidacji w państwach postkomunistycznych”. In J. Marszałek-Kawa, A. Chodubski (Eds.), Wielowymiarowość politologii. Toruń: Wydawnictwo Adam Marszałek.

Domarańczyk, Z. (1990). 100 dni Mazowieckiego. Warsaw.

Jarosz, Z., Zawadzki, S. (1980). Prawo konstytucyjne. Warsaw.

Leoński, Z. (1989). System organizacji i funkcjonowania terenowych organów przedstawicielskich i organów administracji państwowej PRL. Warsaw.

Lipska-Sondecka,A. (2015). Transformacja administracji publicznej w Polsce. Od upadku realnego socjalizmu do czlonkostwa w Unii Europejskiej. Warsaw. 
Lutrzykowski, A. (2018). Przełomowe momenty batalii o samorząd w Polsce. Osiem trudnych lat (1989-1997). Katowice.

Lutrzykowski, A. (2006). "Samorząd terytorialny - wyzwanie ustrojowe. Osiem trudnych lat (1990-1997)”. In G. Radomski (Ed.), Samorząd w polskiej myśli politycznej XX wieku. Toruń.

Lutrzykowski, A. (2014). “Transformacja ustrojowa. Zamknięty rozdział historii Polski czy kontynuacja zmian?”. In J. Marszałek-Kawa, A. Chodubski (Eds.), Wielowymiarowość politologii. Toruń.

Marszałek-Kawa, J. (2019). The Institutional Position and Functions of the Sejm of the Republic of Poland after the Accession to the European Union. Odessa: Helvetica Publishing House.

Marszałek-Kawa, J., Lutrzykowski, A. (2008). Samorząd terytorialny w Polsce i $w$ Europie (doświadczenia i nowe wyzwania). Toruń: Wydawnictwo Adam Marszałek.

Mażewski, L. (2011). Długa dekada lat siedemdziesiątych (1968-1981). Toruń.

Nowak-Far, A. (2008). “Stosowanie acouis de l’Union przez administrację państw członkowskich Unii Europejskiej”. In J. Czaputowicz (Ed.), Administracja publiczna. Wyzwania w dobie integracji europejskiej. Warsaw.

Pokładecki, J. (1996). Samorząd terytorialny w warunkach transformacji systemu politycznego w Polsce. Poznań.

Rybicki, Z. (1988). Szkice o administracji. Problemy prawno-organizacyjne. Warsaw.

Sowa, A. L. (2011). Historia polityczna Polski 1944-1991. Kraków.

Szewc, T. (2006). Dostosowanie prawa polskiego do zasad Europejskiej Kart Samorzadu Terytorialnego. Bydgoszcz-Katowice.

Regulski, J. (2000). Samorząd III Rzeczypospolitej. Koncepcje i realizacja. Warsaw.

Żukowski, M. (2011). Dzieje administracji w Polsce w XX wieku. Warsaw. 